\title{
The Sumerian Law Code compared with the Code of Hammurabi
}

(Read at the Entente Conference of Orientalists, Paris, Juiy, 1920.)

By Professor S. LANGDON, M.A.

THE great Semitic digest of laws made by Hammurabi and inscribed at his orders on the magnificent diorite stele of Susa was probably promulgated soon after the 34 th year of the reign of that famous king, ${ }^{1}$ or about 2088 . His reign extended to 2081 . The period of its composition and promulgation is therefore limited to the brief space of eight years at the end of his reign. This date is at any rate certain for the great stele deciphered by Père Scheil (1902). Fragments of the same code written on clay tablets of the period of Hammurabi were found at Susa, ${ }^{2}$ at Ellasar or Warka, ${ }^{3}$ and at Nippur. From Nippur two large tablets have been recovered, one of which has the colophon, "Fourth tablet of "When the far-famed Anu '." 4 Since the Code as written on the Paris Stele begins "When the far-famed Anu", it is evident that the editions written on tablets are based upon the monumental copy and that they are later than it. For it is highly improbable that the original tablet edition began with a long historical prologue. The Nippur tablet has a

1 This statement is based upon references in the prologue of the code which can be connected with facts of his reign mentioned in date formulæ. The date formula of the 35th year which mentions Mari and Malgû is the highest date which can be verified by the prologue, col. iv, 12 and 30 . In this date Hammurabi claims to have destroyed the walls of Mari and Malgû cities on the middle Euphrates. For the formula see Poebel, BE. vi, 65 , where it is erroneously assigned to the 37 th year; for this formula as the date of the 35th year see Boissier, RA. xi, 162, and Clay, Miscellaneous Inseriptions, No. 33, 6.

${ }^{2}$ Scheil, Delegation en Perse, x, pl. $9=$ Ungnad, Keilschrifttexte der Gesetze Hammurabis, 36-7.

${ }^{3}$ Clay, Miscellaneous Inscriptions, No. 34.

4 Langdon, Historical and Religious Texts, No. 22. I wrote on p. 49 of my volume in the conviction that the Constantinople tablet represents an edition anterior to that of the Paris Stele, but I am now convinced that this copy is later than the monument. 
colophon which says that it is the $a l-g u b-b a$ of the king Hammurabi. ${ }^{1}$

A very large tablet containing several laws which were destroyed on the Paris Stele, and containing about twelve columns of the royal promulgation, was found at Nippur. ${ }^{2}$ The colophon being lost, it is impossible to determine its date with reference to the stele. There is one feature about the Philadelphia tablet which is of exceptional interest. For $\S \S 113$ and 120 it has a Sumerian title $d i-d \hat{\imath} b-b a$ nig $e ́-z i-g a$, "Judgment rendered concerning what is taken from a house." $\S 113$ concerns the theft of grain from a silo or granary, and $\S 120$ the violation of trust on the part of a banker or storehouse keeper who steals grain in his keeping. ${ }^{3}$ It is, therefore, obvious that the Semitic code was modelled upon Sumerian judicial procedure and Sumerian methods of codification. The laws of both peoples are based upon a long history of case decisions, and hence the Sumerian word for law means a "judgment made known". The Semitic word for law, $d \hat{\imath} n u$, really means a legal decision, and the royal legislation of Hammurabi was known to Assyrian scribes as the dināni [ša] Hammurabi, " The judgments of Hammurabi."

Long before tablets of Sumerian law codes were discovered a great many Sumerian legal decisions or rulings on disputes

1 The colophon is obscure and badly preserved. It is not necessary to assume, from what we can now read on the tablet, that it was actually written in the reign of Hammurabi.

2 Published by Dr. Arno Poebel, Historical and Grammatical Texts, No. 93. Translated by Scheil, RA. 13, 49-53, and Poebel, OLZ. 1915, 162-9, 194-200, 225-30, 257-65.

3 Poebel, OLZ. 1915, 263-4, saw the importance of this Sumerian superscription, and suggests that there may have been a group of laws called di-dib.ba nig é-zi-ga. By restoring V R. 24a, 27f, Poebel showed that $d i-d i b-b a=d \hat{\imath} n u$ suhuzu, "judgment taught," i.e. decision which the judges caused the litigants to know, and simittu, Iaw. A Berlin vocabulary (unpublished) has di-dib-ba= didibtû, dînu dânu, dênu parsu, dînu šuḩuzu. The ordinary Sumerian word for "judgment rendered" is di-til-la= dînu gamru, VR. 24, 29. For the sign $K U$-ba in this Sumerian superscription as a variant of $L U(d i b)$ note, beside the citations in OLZ. 1915, 264, and RA. $\mathrm{xv}, 37$, the title of a priest zabar-KU-ba, Thureau-Dangin, SAK. 194, x, 8, for zabar-dib-ba, CT. 24, 3, 18, etc. 
by Sumerian law courts were known. ${ }^{1}$ We now possess about sixty quite well-preserved documents of this kind, all from Lagash of the period of the Ur dynasty (2474--2357). In the legal phraseology of this city the term for a judgment handed down by the courts was di-til-la. ${ }^{2}$ A syllabary of the late period renders this phrase by dînu ga-am-ru, "judgment completed." The phrase of the earlier period of Sumerian judicial procedure does not appear in Semitic. ${ }^{3}$

All the published Sumerian lawsuits from Nippur are of a late period, and here we find the Sumerian term $d i-d i b$, to cause a decision to be received, which passed into Semitic as the ordinary term. A tablet of proceedings before a law court dated in the 33rd year of Hammurabi, that is, immediately preceding the promulgation of the Semitic code, has the phrase $d i$-dib-dúg, or a strengthened form of the compound dib. di-bi pubrum Nibru-(ki)-ka dîb-bi-be-ne-in-dúg, "The council of Nippur shall cause their judgment to be received." " The Semitic laws of the period, therefore, reveal. everywhere the terminology of the Sumerian judicial procedure of the period of Isin and the first half of the first Babylonian dynasty.

All our evidence pointed to the existence of Sumerian law codes as the prototype of the Code of Hammurabi, and when Professor A. T. Clay discovered a large tablet of a compilation

1 The first attempt to interpret Sumerian lawsuits was the article by F. Pélagaud in Babyloniaca, iii, 81-132, based upon tablets previously published by Thureau-Dangin and some new ones copied by Virolleaud in Constantinople, which are published at the end of Pélagaud's article. All these tablets came from Lagash. Later H. de Genouillac published a number of similar texts in Inventaire des Tablettes de Tello in the Musée Imperial Ottoman, vol. ii, pt. i. On the basis of these and the tablets previously published Genouillac made a study of Sumerian legal decisions in RA. viii, 1-32. In the second part of vol. ii Genouillac published a large number of these texts, also from Lagash and now in Constantinople.

2 The reading $D I(d i)=d \hat{\imath} n u$ is no longer in dispute. My former reading sá-til-la was erroneous. Syl. B. $185, d i-i=d \hat{n} u$, is now confirmed by the Chicago Syllabary, 88.

3 But compare ti-ma-su-nu-ti ig-mu-ru, Schorr, Altbabylonische Rechtsurkunden, 261, 35.

- Poebel, BE. vi, No. 10 ; see ibid., p. 47 ; Schorr, ibid., No. 292. 
of Sumerian laws and published ${ }^{1}$ it in 1915 the theory of a Sumerian prototype was confirmed. Only the reverse of this important tablet from Erech (?) containing nine laws is preserved. In the colophon the laws are called $t i$-la of Nidaba and Hani, or the decisions of Nidaba and Hani. ${ }^{2}$ Tila is apparently an abbreviation of $d i-t i-l a$, a phrase characteristic of the Lagash school and of the earlier (Ur) period. When I was engaged upon the catalogue of the Nippur Collection in Philadelphia I came upon a few tablets of this kind, and I found time to publish only one of them, $\mathrm{Ni} .4573$, a fragment from the top of a single-column tablet. ${ }^{3}$ I am unable to make any connected sense from this fragment, and, in fact, it is not at all certain whether it should not be regarded as a code of precepts for learners in the schools. ${ }^{4}$ Two double-column tablets of the collection are extremely important, and together they carry seventeen laws. Ni. 8284 and its duplicate, in fragmentary condition, $13632+13647$, has been published by Dr. Lutz in vol. i, pt. ii, of Publications of the Babylonian Section, University Museum, Philadelphia, No. 101 (duplicate 100). Since this tablet ends in the midst of a law the Sumerian code was clearly continued on a succeeding document. It is extraordinary that the tablet has no colophon to tell us its position in the series. The method of redacting long liturgies in series of small tablets was already employed in this period and in the schools at Nippur. ${ }^{5}$ Ni. 8326, published by Lutz as No. 102, is sadly damaged on the reverse. It, like No. 101, probably contained no colophon. In the Revue d'Assyriologie, xvii, 35-43, the able French scholar, Professor

1 Miscellaneous Inscriptions in the Yale Babylonian Collection, No. 28. The author gave an interpretation of this tablet on pp. 18-27.

2 For the grain goddess as patroness of writing and her consort Hani, also a patron of writing at Umma, see, in addition to Clay's discussion, p. 19, the writer's Tammuz and Ishtar, p. 153.

3 Sumerian Grammatical Texts, No. 30, republished by Lutz, Selected Sumerian and Babylonian Texts, No. 98.

4 Note that the tablets of laws in the Nippur Collection are all doublecolumn tablets.

5 See the writer's Babylonian Liturgies, p. xlix 
Scheil, wrote an edition of Nos. 100-2 in Lutz's volume. The successful decipherer of the Code of Hammurabi places himself again on record as the first interpreter of these two tablets. I have seldom realized the advantage which a second interpreter has received at the hands of one who led the way.

I have arranged all the published Sumerian laws in the arbitrary order given below. Naturally the Nippurian redaction may not have been the same as the code of Ellasar or Erech. The three tablets of the law here edited certainly do not follow each other consecutively, and their positions in the Sumerian code remain wholly uncertain. But enough consecutive material is available to show that we have here a real code arranged on scientific principles; the laws on various subjec.s are grouped together. But it will be seen that with rare exceptions the Sumerian laws are not literal originals of the Semitic code. The two codes resemble each other much in content and phraseology, and Sumerian law was obviously the forerunner of Semitic legislation. In my analysis of the twenty-six laws now recovered I follow the order provisionally assigned to them in my paper.

(1) $\S \S 1-3$, concerning care and protection of gardens. This subject is dealt with much more fully in $\$ \S 59-65$ of the Hammurabi Code.

(2) $\S 4$, concerning responsibilities of neighbours. No corresponding Semitic law, unless it be $\S 67$.

(3) $\S 55-8$, concerning slavery. Slavery in Sumer dates from prehistoric times and probably originated in the custom of reducing captives to the condition of servitude. The primitive ideograph for slave consists of the sign NITAH (male) and KUR (foreign land), " male of a foreign land," and in Sumerian this was apparently pronounced $e r, u r{ }^{1}$

1 e-rum $=a r d u$ in BM. 38744. The pronunciation e-ri is certain and in early texts the ideograph is followed by ra, i.e. er-ra. See Clay, Miscellaneous Inscriptions, 4, iii, 1 ; Nikolski, No. 19, Obv. v, 6. 
The laws pertaining to slaves are not grouped together in the Code of Hammurabi, but are given in various parts of the code in those sections (on marriage, debt, personal injury, etc.) which involve the subject of slavery. The same principle probably obtained to a less extent in the Sumerian code, but in $\$ \S 18-19$ below the rights of a slave woman are not secured at all, which seems to indicate an advance in the standing of slaves under Semitic law.

The subject of runaway slaves is discussed in $\S \S 15-20$ of the code. Here the laws are more comprehensive and cover nearly all possible circumstances. A freeman who aids a palace slave or a poor man's slave to escape from a city is slain. If he gives refuge to a slave of the palace or a poor man's slave and does not produce him at the governor's proclamation he is slain. If he captures a runaway slave and restores him he receives two shekels. If the owner's name cannot be found he shall convey the slave to the palace and the authorities shall find the owner. If he capture a slave and confine him in his house and the slave is stolen from his house, that freeman is slain. If the slave escape from his captor he shall swear to the fact and go free.

In comparison with these laws the Sumerian ruling is primitive and far less severe. From it we gather that the Sumerians ordinarily held a slave to be worth 25 shekels. ${ }^{1}$

$\S 6$ corresponds to $\S 282$ of the Code of Hammurabi, where a slave who falsely denies his owner has his ear severed.

$\S \S 7$ and 8 provide in a merciful manner for a slave afflicted with incurable disease. He receives royal alms, and in case he takes refuge with a freeman he shall be protected and conveyed to a house provided for such cases, or to some place where he may wish to go. ${ }^{2}$ There is nothing similar to this law in the Code of Hammurabi. $\S 278$ provides for the return of a

\footnotetext{
1 Prices of slaves vary greatly in Semitic contracts. Note the high price, 50 shekels, for a slave girl, in Schorr, Altbabylonische Rechtsurkunden, No. 84, and 12 shekels for a male slave, No. 85 .

2 So $I$ interpret the law, but it is obscure and uncertain.
} 
purchased slave if the bennu disease befall him within a month of his sale. Bennu is obviously the same disease as miktum in the Sumerian code; the two words indicate the same disease as we otherwise know from Virolleaud, Astrologie, Sin xix, 10.1 A royal gift to petty officers $(r \bar{e} d \hat{u})$ is mentioned in $\S 34$ of the Code, but there is no reference in Semitic law or contracts to royal alms for the helpless poor.

(4) $\S 9$, concerning false accusations. Corresponds to $\S \S 1-3$ of the Code. See the note at the end of my translation. See also $\S 127$ of the Code on false accusation of a woman's chastity, for which a freeman is reduced to slavery.

(5) $\S$ 10-11. $\S 10$ probably began a group of laws on property and taxation. $\S 10$ corresponds to $\S 30$ of the Code.

(6) $\S \S 12-17$, concerning marriage and the family. The Code has a long section on marriage and the family, $\$ \S 128-195$. In both codes this is by far the most lengthy section. The Sumerian section certainly began on some lost tablet, and probably continued for several paragraphs after the break at the end of $\S 17$.

$\S 12=\S 167 ; \S 13=\S 171$. In each case the resemblance in legislation is great. $\$ 14$ probably does not appear in the Code ; it appears to make legitimate the children of a concubine which she bears to her master after his wife's death.

$\S 15$ corresponds to no law of the Code. The profession of a hierodule, karlil, was confined to free-born women. ${ }^{2}$ Sumerian law permitted a man whose wife was childless to beget heirs from a temple hierodule. Now karlil is rendered into Semitic by harimtu and kizritu, ${ }^{3}$ and kizritu is probably identical with zikritu by metathesis. For zikritu the ordinary

1 See also CT. 19, 22, 9-11, miktum as synonym of bennu. Sudhoff has come to the conclusion that this means epilepsy, Schorr, ibid., p. 129.

${ }^{2}$ Note that a woman adopts a girl and makes a hierodule of her. Poebel, BE. vi, 4.

3 Shurpu, v, 144.

JRAS. OCTOBER 1920. 
Sumerian word is a pseudo-ideogram [sal zi-ik-]ru=zikritu, Rm. 2, 26, rev. 11. In the Code of Hammurabi the temple harlots, sal zi-ik-ru-um, are mentioned with the priestesses and are probably identical with the lear-lil of the Sumerian code. She inherits her father's property on the same terms as a son, and when she dies her inheritance goes to her brothers $(\$ 180)$. Hence she could not marry. $\$ 187$ provides for the adoption of children of a zikritu or hierodule, and leaves the impression that such children are state property who cannot be claimed by their mother. Such a son when adopted is severely punished for denying his adoptive parents ( $\$ 192){ }^{1}$

$\S 16$ deals with a case of adultery, the violation by enticement of a freeman's wife. The penalty imposed upon the co-respondent is not stated. The wife is not divorced, but the violation permits the husband to take another wife. The Semitic code, $\S 129$, concerns the same kind of adultery, that is, the unfaithfulness of the wife is implied and the penalty is death for both. Here, again, Semitic law is much more severe, and involves a more serious estimate of the crime.

$\S 17$ probably corresponds to one of the paragraphs 159 , 160, 161 of the Code.

(7) §§ 18-19, concerning injury to pregnant women. Corresponds to $₫ \S 209-14$. See the note on $\S 19$.

(8) $\S 20$, concerning damage to a rented boat. This subject is dealt with in $\S \S 236-8$ of the Code.

(9) $\S 21-2$, concerning adoption. $\S 22$ seems to be a repetition of the end of $\S 21$, and the whole section refers to penalties of breaking faith in adoption on the part of both child and parents. In my note on $\S 21$ the reader will find that this law is well illustrated in Sumerian and Semitic documents, and it should

1 The sacred women of the land Emutbal are brought to Babylon by the orders of Hammurabi, see King, Letters and Inscriptions of Hammurabi, No. 34 = Ungnad, Babylonische Briefe, No. 2. Here the two orders of priestesses, istaräti and kizrêti, are mentioned. Both King and Ungnad erroneously rendered ištaräti by "goddesses". The word is the plural of ištarîtu, harlot. See Tammuz and Ishtar, p. 80 . 
be in the Code, possibly in the part not yet recovered. $\S \$ 185-93$ of the Code protect the rights of adoptive parents and adopted children.

(10) $\S \S 23-4$ belong under section 6 above, and correspond to no laws in the Code.

(11) $\S \S 25-6$, on the obligations of ox-herds. $\S 25$ probably corresponds literally to $\S 262$ of the Code, of which only two lines are preserved.

The Code distinguishes between nälkidu, ox-herd, and re'u, shepherd. If a lion slays oxen or sheep in the fold of a shepherd the loss is borne by the owner $(\S 266)$. The business of the nākidu or Sumerian gud-nigin seems to have been more in the nature of a guardian who was responsible for the safety of his charges. $\$ 26$ corresponds precisely to $\S 263$ of the Code.

Lutz No. 101

1. tukunditi

2. galu galu-*ur 1

3. gišs-šar gis̀ gub-bu-dé2

4. kislag. ${ }^{3}$ in-na-an-š̃g

5. kislaj-bi

6. gišššar giš-gub-bu-dé

7. $n u$ ni-in-tíl

\section{$\S 1$}

1. If

2. a man to a man

3. for planting a garden with tree

4. gave vacant land

5. (and) this vacant land

6. in planting with trees

7. he finished not

1 For the sign U with value ur see Sumerian Grammar, 254, ur 15, and for the construction, Poebel, BE. vi, No. 11, 21, ud kur-š́ galu galu-ur, " In future days man against man (shall not complain)." ur is for the ordinary $r a$. For postfixed $u r=r a$, see Sum. $G r$., $\$ 81$ end and $u r=a n a$, ina, Poebel, PBS. v, 105, iii, 6 Radau, Ninib No. 1, i, 28, Gimil-Sin-mu-ùr, "To my (king) Gimil-Sin."

2 Cf. Code of Hammurabi, $\S 60$, ana kirîm zugāpim and my restoration of II Raw. 15, 22, in RA. 14, 18, giš-sar gǐs-sub-ba-ta = kirâ ana zakcapi. The difficult passage in the Tammuz hymn SBP. 330, 10, is now intelligible, $b a-s i-i n-\bar{u}[g i \xi-s a r] g i \xi-m i-n i-i n-g u b$, "Mount thou up and plant the gardens." For gi $s$-gub in the poetical sense "to instal a ruler", see Sumerian Liturgies and Psalms, 256, 23.

${ }^{3}$ kisla $\dot{g}=$ terîtu, vacant, i.e. land without buildings, see Schorr, VAB. v, 418, 24, and Poebel, BE. vi, 12, note 2; Thureau-Dangin, RA. 11, 96.

4 See the commentary of ana itti-su, RA. 14, 18, 26, and Code $\S 61$. 


\section{8. galu giš-šsr in-gub-ba ${ }^{1}$}

9. ร̌ag $\dot{g} a-l a-b a-n a-k a$

10. kislag̉ ba-ra-ab-šub-a

11. in-na-ab-sum-mu

12. tukundibi

13. gǐ-šar galu-ka

14. in-éd

15. nam-ma!?)-dúr ba-ku
8. to the gardener who did the planting ${ }^{2}$

9. in his share of it ${ }^{3}$

10. the (part of the) vacant land which was neglected

11. shall be assigned.

$\S 2$

12. If (a man)

13. the garden of a man

14. takes over

15. and pollenates it not but neglects it

16. 10 gìn ${ }^{4} k$-babbar ni-lal-e 16. he shall pay ten shekels of silver.

This paragraph corresponds apparently to the Code $\S 65$, where the provision against such neglect is more logical. A negligent gardener according to the Code must pay the owner of the garden in produce in the same proportion as that of an adjoining garden which had been properly cared for.

\section{7. tukundibi galu}

18. giš-šar galu-ka

19. giš in-sīg

20 maš ma-na kù-babbar

21. ni-lal-e

\section{$\S 3$}

17. If a man

18. in the garden of a man

19. has cut wood

20. $\frac{1}{2}$ mana of silver

21. he shall pay.

The law is almost identical with the Code $\S 59$, but the latter is again more exact and logical, since it restricts the penalty to those cases in which the owner of the garden was unaware of the trespass and theft of the woodcutter.

1 Var. omits the subjunctive inflection. Cf. Code $\$ 62,40$, $k$ a innadn.

${ }^{2}$ Note $g u b=z a k \bar{a} p u$ in the same sense as gižsub. Cf. CT. 19, 47, 21.

${ }^{3}$ Note the neuter suffix $b a$ and the personal suffix $n a$, and for this principle see Sum. Gr., \$ 160.

4 The reading gin $=$ sizlu is confirmed by Meek, AJSL. 36, 158, 25, $T U(g i-e)=$ sillu. 
$\S 4$

22. lukundibi galu

23. $\dot{e}-e$ uš-sa-ni

1. kislaig galu al-šub

2. lugal é-a-ge

3. galu kislaj-ra

4. kislaj-zu al-šub

5. é-mu galu gib ${ }^{1-d e ́}$

6. $\dot{e}-z u$ kala-ga-ab

7. in-na-an-dúg

8. enim-enim keš-du-bi

9. un-da-an-gi-en

10. lugal kislaj-a-ge

11. lugal é-a-ra

12. nig ú-gu-de-a-ni

13. $i n-n a-a b-s u-s u^{4}$
22. If a man's house

23. is beside

CoL. II

1 vacant land of a man which is neglected

2. and the owner of the house

3. to the owner of the vacant land

4. "Thy vacant is neglected;

5 . in order to seclude ${ }^{2}$ my house

6. strengthen thou thy house,"

7. said,

8. and the words concerning the agreement

9. be established, ${ }^{3}$

10. the owner of the vacant land

11. to the owner of the house

12. for whatsoever he lost

13. shall indemnify.

The meaning of this law seems to be clear enough, but the statement is made in a confusing manner. A man has built a house, one side of which is supported by the wall which separates his plot of ground from his neighbour's field. He enjoins his neighbour to strengthen his wall, and if he neglects to do so the neighbour is penalized to pay any loss

1 For $G I+G I=g i b$, v. Ebeling, KTA. 8, 3,ab-gib-bi=ušapraku and CT. 17, 31, 3, sag-ba-an-gib-ba =iprik. Scheil reads ni-šár-ne, "ma maison on va agrandir."

2 Literally " turn away man".

3 Or enim-gi (?), "to revoke a promise"; see Gudea, Statue B, I 14 ; Thureau-Dangin, SAK. 52, xi, 13 ; Langdon, Poème du Paradis, 226, 37. The rendering adopted here agrees with that of Scheil, and for enim ka-kesda, to make an agreement, see Sumerian Grammar, p. 224.

${ }^{4}$ For $s u=$ rábu, repay, cf. $s u=a p a ̄ l u ~ z a ~ h a b u l l u$, AO. 3930, rev. 17. See also Ungnad's restoration of the Code $\$ 73$, mimma [ša halku] i-ri-[a-ab]. 
incurred to the owner of the house. Confusion to the interpreter is caused by the reference in line 6, "strengthen thy house," but there is otherwise no reference to a house on the adjoining property. The word "house" is employed loosely for wall. The corresponding law in the Code is probably $\S 67$, only a few words of which have been preserved. For contracts concerning dividing walls, see Schorr, Altbabylonische Rechtsurkunden, Nos. 198-201.

14. tukundibi

15. geme $\operatorname{arad}^{1}$ galu-*ur $^{*}$

16. šag-uru-ka ba-zaij

17. é galu-kw

18. áś iti-ám

19. $n i-k u-a$

20. ba-an-gi-en ${ }^{2}$

21. sag sag-gim

22. $b a-a b-s u m-m u$

23. tukundibi

24. $\operatorname{sag} n u-t u$ b
14. If

15. a female slave or a male slave from a freeman

16. in a city escape

17. and in the house of a freeman

18. for one month

19. take up abode

20. and he (or she) be confirmed (as the owner's)

21. slave for slave.

22. he shall give

23. If

24. he have no slave

${ }^{1}$ In this period the Sumerian word for slave eri, erra, is replaced by the Semitic arad; see, for example, VS. i, No. 27, 14 ; Gudea, Cyl. B. 18, 21. Not until the Semitic period of Sargon the Ancient does the sign for female servant $S A L+K U R$ appear, Thureau-Dangin, RTC. 80, obv. 2, developed out of an older sign REC., p. 6, second form of $N I T A H+K U R$. In fact, the early inscriptions write male and female slave with $K U R$ inserted into variant forms of the same sign. For the masculine sign see Nikolski, No. 19, v, 6, and the feminine sign at line 11, rev. i, 1, et passim. When the new sign for geme, female slave, was invented the old sign for female slave is then written for male slave and the original form for male slave is abandoned. Consequently on this tablet arad, slave, is written with a sign which in pre-Sargonic times indicated a female slave.

2 For gin as a technical term in deciding suits at law, see ThureauDangin, RTC. 290, R. 4; Genouillac, Inventaire, 172, 6; 830, rev. 7 and 923. See below Col. iii, 11 . 


\section{CoL. III}

1. 25 gin ku-babbar

2. ni-lal-e

3. tukundibi

4. arad galu-ge

5. lugal-a-ni ir

6. vam-araà da $n i$

7. ba-an-da-gur ${ }^{1}$

8. lugal $a-n i-i r$

9. nam-arad-da-ni

10. $a-r a ́ a ́ d m$

11. un-gi-en

12. $k i s i^{2}-b i$

13. al-bür- $e$

14. tukundili

15. $m i$-ik-tum

16. nig-ba Tugal-kam

17. $n u-u b-d a-a n-k a ́ r-i$

17. tukundibi

18. $m i$-ik-tum

19. ni-te-a-ni-ta
1. 25 shekels of silver

2. he shall pay.

$\S 6$

3 . If

4. the slave of a freeman

5. against his master

6. concerning his servitude

7. has brought complaint,

8. and to his owner

9. his servitude

10. twice

11. be confirmed,

12. upon his forehead

13. shall one incise a mark.

$\S 7$

14. If

15. there be a malady

16. there shall be a gift of the king.

17. Not shall he be left destitute

$\S 8$

17. If

18. there be a malady

19. and of his own free will

1 Cf. Thureau-Dangin, RTC. 290, 9, murgu ba-gur-ra-ta, "after she had turned," i.e. brought complaint. Scheil discovered the connexion between this law and $\$ 282$ of the Code.

2 The sign is the early Babylonian form of SAI. $7487(k i-s i)=$ muttatu, forehead. For the Sumerian value see Rm. 2, 588, obv. 30, in AJSL. 36, 158 , and CT. $18,32 b, 10(k i-s i)=$ variant, RA. 10, 82, v. 32, which has by confusion SAG. Note Syl. B. ${ }^{1}$ iv, 35 , where kiš $i$ is followed by SAG. In line 13 bur clearly means "brand", "cut", for which the Semitic texts have muttata-su ugallabu, Code $\$ 127$, and for the branding of a slave who denies his master, see Daiches, LSS. $\mathrm{i}^{2}$, No. 26,$9 ;$ bur $=$ galābu is not documented, but buir does mean to cut, tear, salātu, Arabic salata, and this is probably the sense here. 
20. galu-*ur $u n-s i-d u$

21. galu-bi

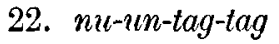

23. $k i^{1} s^{2} a g-g a-n a-s^{2} u$

24. $\dot{y} a-b a-r a ́ a$
20. he come to a freeman

21. that freeman

22. shall not reject him

23. but to the place of his desire

24 . he shall cause him to go.
1. tukundibi

2. galu galu-*ur

3. á nu-gar-ra-ta

4. enim nu-zu-ni

5. in-da-lal ${ }^{2}$

6. $g c, l u-b i$

7. nu-un-gi-en ${ }^{3}$

8. enim in-da-lá-a

9. nam-tag-ga-ba ġe-il-e
CoL. IV

$\S 9$

1. If

2. a man against a man

3. for a deed (?) which was not done,

4. for a matter which he knew not

5. has brought accusation,

6. and that man

7. has failed to prove it,

8. as to the matter which he accused him of

9. let him bear the penalty.

The wording of this law is again indefinite and written to cover all degrees of accusations with their corresponding penalties. It corresponds to at least three paragraphs of the Code. $\S 1$. If a man áccuse a man of a deed which involves murder and fails to prove it he shall be slain. $\S \S 2$ and 3 . If a man bear witness in a lawsuit and fail to prove his statement he shall pay the penalty involved in the case. That is, if his false evidence involve the life of a man he himself shall be killed. If the case involve grain or money he must pay grain or money, as much as the defendant would have

1 Copy by Lutz has $D I$, perhaps sá śag-ga-na(?). One expects kisaggana to mean a house of quarantine, pest-house, but no word for such an idea is suggested by raggan. The phrase occurs in my Histcrical and Religious Texts, No. 54, 4. Scheil adopts the reading $D I$, and renders "au tribunal de son choix".

2 lal, bind, accuse, is rendered by ubburu in the Code, see $\S 1$.

${ }^{3}$ gi-en corresponds to ukt $n$ in the Code. 
paid had he been convicted. The Sumerian law above stands on a lower stage of lawgiving put upon the same level of justice.

10. tukundibi

11. lugal e-a

12. ì nin é-a-ge

13. gú $-u n^{1} e^{\prime}-a$

14. in-šbb-bu-tum ${ }^{2}$

15. galu kur-e in-ila

16. $m u-3-k a m-m a-k a$

17. $n u-u b-t a-\grave{e}-e$

18. galu gú-un é-a

19. in-il-la

20. é-bi ba-an-tum

21. lugal é-a-ge

22. enem nu-um-gà-gà-a

\section{$\S 10$}

11. the owner of a house

12. or the mistress of a house

13. the burden of taxation on a house

14. has abandoned and has taken himself off,

15. and another man has borne it,

16. and for three years

17. he has not ejected him,

18. the man who has borne

19. the burden of taxation of the house

20. shall take that house.

21. The owner of the house

22. shall not protest.

This law corresponds closely with $\S 30$ of the Code, but the $i l k u$ in the Semitic law is borne by soldiers only, and clearly refers to crown lands held by men who served in the army, otherwise the provisions of the older Sumerian law are precisely similar to those of Hammurabi. The Semitic law is : "If a sergeant or a common soldier has abandoned his field, his garden, or his house before the burden of taxation and has taken himself off, and another after this has seized his field,

1 This passage yields at last the Sumerian w ord for $i l k u$, state tax, tribute, and shows that ilh $u$ is a synonym of billu. Cf. Haupt, AKKT. 215, 24, gìn-gar-zi-da = tax collector, i.e. the one who fixes the tribute.

2 This phrase, although ungrammatical, is clearly equivalent to iddima uddabbir, "he abandoned (the field, etc.) and fled." Code $\$ 30$. tum, therefore, means dapāru, to remove, drive away, and we have here an example in Sumerian of two verbal roots of different meanings placed logether and conjugated with a single verbal prefix. 
his garden, or his house, and has paid the taxes thereon for three years, if then he has returned and desires his field, his garden, or his house, not shall it be given to him. He who seized it and paid taxes thereon shall exercise the duty of crown property."

\section{$\S 11$}

23. tukundibi

23. If

24. lugal é-a

24. the owner of a house..

Here the tablet ends and the law was continued on a following tablet. Naturally, this law corresponded to to $\S 31$ of the Code. This provides for the restoration of the property in the event of the owner returning after one year.

LuTz No. 102

1. tukundibi

2. [dam] egir $-r a$

3. ba-an-tuk-a

4. dumu in-ši-in-tu-ud

5. $\operatorname{sag}-P A K A B D U^{1}$

6. e ad-da $n \dot{\alpha}-t a$

7. mu-un-túm-ma

8. dumu-na-ka

9. dumu dam nitalam ${ }^{2}$

10. ̀̀ dumu dam agir-ra

11. nig-ga ad-da-ne-ne

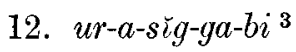

13. ni-ba-e-ne

\section{$\S 12$}

1. If

2. a second wife

3. he has married

4. and she has borne him a son

5 . the dowry

6. which from her father's house

7. she brought

8. shall be her son's.

9. The son of the wife who was first chosen

10. and the son of the second wife

11. the property of their father ${ }^{4}$

12. equally

13. shall divide.

1 This passage supplies the Sumerian word for siritutu.

2 nitadam, nitalam $=$ hairu, hairtu, always refers to the first husband or wife in a marriage.

3 mitharis, Code $\$ 167$ end, mitharis $i z u z z u$.

- Note that this passage confirms the reading namkur bit abim in $\S 167$ of the Code. 
This law has much similarity to $\S 167$ of the Code. "If a freeman married a wife and she bore him sons and that woman went to (her) fate, and after her he married another woman who bore him children, after the father has gone to his fate the sons shall not divide according to the capital. They shall take the dowry of their mothers and divide equally the property of the house of the father." Here, again, the Semitic law is more explicit and juristically exact.

\section{$\S 13$}

14. lukundibi galu-*ur

15. dam im-tuk

16. damu in-š $i-i n-t u-u d$

17. cumu-bi in-til

18. ù geme lugal-a-ni-ir

19. dumu in-š-in-tu-ud

20. $a d-d a-a$ geme

21. udumu-ne-ne

22. ama-ar-gí-bi in-gar

23. dumu geme-ge

24. dumu lugal-a-na-ra

25. é nu-un-da-ba-e
14. If to a man

15 the wife whom he married

16. bore him a son

17. and that son lived,

18. and a handmaid to her master

19. also bore a son,

20. and the father to the handmaid

21. and her sons

22. gave them their freedom,

23. the son of the handmaid

24 . with the son of her master

25. shall not divide the house.

This law has considerable resemblance to $\S 171$ of the Code. "And if a father in his lifetime to the sons whom a handmaid bore to him did not say 'My sons', after the father went to his fate, from the property of the house of the father the sons of the handmaid with the sons of the wife shall not take a portion. Freedom to the handmaid and her children shall be given." The Semitic law then goes on to make provision for the widowed wife and the conveyance of her property to her children after her death.

\section{$\S 14$}

26. tukundibi

27. [dam] nitalam-a-ni

28. $[i n]-d \bar{\imath} g$
26. If

27. his wife, the one firs ‘ chosen, 28. has died, 
29. egir dam-a-na-ta

30. [geme?]ri nam-? -ku

31. ba-an-tuk-tuk

32. ...

33. dumu [

34. duпıน [

35. lugal-a-ni-[ir]

36. in-ši-in-tu-ud

37. dumu dumu-šú gîn-n[a]

38. $\dot{e}-a-n i i b-d \grave{u} g-g[i]$

39. tukundibi

40. $g a^{7} u-* u r$

41. dam-a-ni

42. dumu nu-un-ši-in-tu-ud

43. $k a r-l i l-d a^{2}$

44. ${\text { tilla } a-a^{3}}^{3}$

45. dumu in-ši-in-tu-ud

46. kar-lil-ba

47. $s e-b a i d a-b a$

48 sig-ba

49. in-na-ab-sim-mu

50. dumu liar-lil-dé

51. in-ši-in-tu-ud-da

52. ibil-ni ni-me-en ${ }^{4}$
29. and after the death of his wife

30. his handmaid (?) . . .

31. he took

32. ? ?

33. A son ...

34. A son ...

35. to her master

36 . she bore

37. son like son

38. his house shall enjoy (?) ${ }^{1}$

$\S 15$

39 . If

40. to a freeman

41. his wife

42. bore a son not,

43. and a hierodule

44. in the highway

45. bore him a son,

46. to that hierodule

47. sustenance in grain, oil

48. and wool

49. he shall give.

50. To the son of the hierodule

51. whom she bore to him

52. "He is his son" (he shall say).

1 The meaning is obscure and the verb dug has never been found in a similar passage.

${ }^{2} d a$ is probably the noun augment here, unless a line in-da-ná-a has been omitted. See Poème Sumérien du Paradis, 160, n. 3 .

3 For $A N-A S \cdot A N$ (tilla) =zûku, šulù, street, rîbu, ribâtum, carrefour, see Keilschrifttexte aus Boghazkoi, i, No. 40, 14-17. As a commentary on this passage compare the omen, Babyloniaca, iii, 217,47 .

${ }^{4}$ Here, again, a line has been omitted. Supply $n i$-da-an-dug $=i k t a b i$, cf. Code $\$ 170$, line 45 . We expect abil-mu, "thou art my son." This law proves that the hierodule was a free-born woman, and consequently owing to her caste and her sacred profession her children by rape are legitimate. 
53. $u d d a m-a-n$;

54. a-na ti-la-ás

55. kar-lil

56. dam nitalam-ra

57. é-a nu-un-da-an-ku

62. igi-ni ba-ab-gi
63. ùr-ba (?) ba-an-lal-lal 1

62. igi-ni ba-ab-gi
63. ùr-bci (?) ba-an-lal-lal ${ }^{1}$

64. [é]-ta nu-ub-ta-ed

59. tukundibi

60. galu galu-*ur

61. dam nitalam-a-ni

53. As long as his wife

54. lives

55. the hierodule

56. with the wife who was first chosen

57. in the house shall not take up her abode.

$\S 16$

59. If

60. a man

61. the wife, who was first chosen, of a man

62. turned his eye upon

63. and he was taken in her bosom

64. not shall she be sent forth from the house.

\section{Reverse}

1. dam-a-ni

2. dam-sukud ${ }^{2}-n a(?)$

3. $b a$ an-tuk-a

4 dam-eair-ra

5. dam vitalam

6. $n i-i l-i l^{3}$
1. His wife,

2. the wife of his ...

3. whom he has married,

4. (that is) the second wife,

5. the wife who was first chosen

6. shall support

\section{$\S 17$}

\section{7. tukundibi}

7. If

8. mussa tūr

9. é ùr-ra-na-ka

10. ni-in-[tum-ma?]

11. nig-sal(?)-uš(?)-[sa in-šig ?]

12. egir-[ba-ta?]
8. a son-in-law to

9. the house of his father-in-law(?)

10. brought (?) (a tribute)

${ }^{1}$ Cf. $\S 130$ of the Code.

${ }^{2}$ Scheil reads this sign $L I L$.

${ }^{3}$ Semitic ittana $̌ s ̌ i-s ̌$, Code $\S 148,81 ; \S 178$, col. $x v, 8$. 
$13 \mathrm{im} \ldots$

14. $b a \ldots$

$15, b a \ldots$

16. ...

17. $[i n]^{1}-n x-a b \ldots d e ́$

$18 \ldots b i$ ? al(?)ni

19. ...tuk-tuk

$2021 . .$.
13. ...

14

$15 . .$.

$16 . .$.

17.

$18 . \ldots$

$19 . .$.

20.21

Clay No. 28

$\S 18$

1. tukundibi

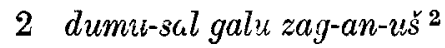

3. $n i g$ šag-ga-ni

4. $a-i m-\check{s} u b-s ̌ u b$

5. 10 gin ku-babbar ni-lal-e
1. If (a man)

2. jostled the daughter of $\mathbf{a}$ freeman

3. and that which was in her interior

4. he caused to fall

5. he shall pay ten shekels of silver.

$\S 19$

6. tukundibi

7. dumu-[sal] galu ba-an-sig.

8. nig šag-ga-ni

9. $a-i m-\check{s} u b-s ̌ s u b^{3}$

10. $\frac{1}{3}$ ma-na ku-babbar ni-lal-e
6. If (a man)

7. smote the daughter of a fresman

8. and that which was in her interior

9. he caused to fall

10. one-third mana of silver he shall pay.

1 So Scheil.

2 For the meaning of $z a g-u \breve{s}$ see OLZ. 1914, 417, which is probably to be distinguished from zag-šsus. Thureau-Dangin, Mission Française de

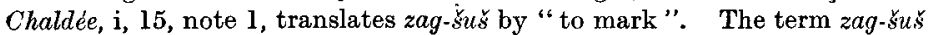
is always employed with animals; see citations in my article in OLZ. and Thureau-Dangin's note, also VS. xiv, 145, rev. 2.

${ }^{3} a-s \tilde{u} b$, a strengthened form of $s_{u} u b=n a d \hat{u}$. For the augment $\dot{u} \mathrm{cf}$. ì-nad, to lie down, Poème Sumérien 'du Paradis, 160, 7. 
The last section is identical with $\S 209$ of the Code of Hammurabi, with the exception of the amount of the fine. Here it is 20 shekels, where the Semitic code has 10 shekels. The circumstances described in $\S 18$ are not considered in the Code of Hammurabi, which, however, in $\$ \$ 210-14$ covers other considerations which are neglected by the Sumerian laws. $\$ 210$ provides for the circumstance that the pregnant woman, daughter of a freeman, dies from the maltreatment. In such case the offender's daughter is executed. $\$ 211$ rules that the offender must pay 5 shekels for similar maltreatment of the pregnant daughter of a poor man, and in case she dies $\S 212$ provides for the payment of a half mana of silver. $\S 213$ rules that two shekels is the fine for causing a pregnant slave woman to lose her child and $\$ 214$ fixes a third mana of silver for her death. These comparisons between the two codes are stated by Clay, ibid., $23 \mathrm{f}$. The Semitic code is much more explicit and comprehensive ; $\S 210$ involves a cruel injustice, and it would be interesting to know whether the Sumerians also had this law.

\section{1. tukundibi}

12. kaskal dúg-ga-ni

13. nar ${ }^{1}$ ri-bal

14. $m a ́ x u ́-g u-b a-a n-d e^{2}$

15. en-na má e-dé ${ }^{3}$

16. $a-b i b a-b a a^{4}-t a$
11. If a man

12. who was sent upon a commission

13. in crossing a river

14. allowed a ship to be lost

15. until he has raised the ship

16. her rent and the decrease in value

$1 N A R$ appears to be Semitic here, ina ebir nāri(?) ri-bal=bal-ri, cf. Ranke, BE. vi, 61, $1+5$.

2 Cf. Code of Hammurabi, $\S 236,34$, whtallik.

${ }^{3} e$-de $=w a \hat{s} u$, usually written $e d$, è. Cf. the Code $\S 238,59, u \not s$-te-li$a-a \xi ̌-s i$. The Sumerian should be rendered ušeși-ašs̆i.

4 Text $m a$, photograph and Clay's copy. $b a-b a>b i-b i=n u \xi u r r \hat{u}$, RA. $13,189,31=$ Brünnow, 116 ; -ta is the conjunction " and" here, see Sumerian Grammar, $\$ 232$. 
17. nam lugal-la-a-ni-šu

18. $n i-a k a-e^{1}$
17. to its owner ${ }^{2}$

18. he shall pay.

I conceive this law to presuppose the following situation. A man was commanded (dúg) to go upon a mission. [Compare the law of Hammurabi in Poebel's new text, translated by Scheil, R.A. 13, 52, col. iii, 10-14, a merchant to a clerk kaspam ana (tadmiktim . . .) iddinma ana harranim ițruzzu, "gave money for making profit and sent him on a journey."] This agent, in crossing a river, caused a ferryman's boat to be lost. The journeyman must pay rent for this boat until it is refloated and also any depreciation in its value. According to $\$ 238$ of the Code, a boat which had been sunk lost half of its value. If nam-šru in line 17 be taken in its literal sense the law should mean that the agent must pay the rent and damages "instead of his master". Against this translation is the word lugal, " master." It is not customary for a freeman to speak of a merchant as his master, and lugal is regularly employed for "owner" in these laws.

19. tukundibi

20. $\operatorname{tug}(?)^{3}$ ad-da-ni ù ama-ni

21. $n u$ ad-da-mu
19. If

20. an adopted child(?) to his father and his mother, 21. "Not my father,

1 On this passage ef. Schorr, Altbabylonische Rechtsurkunden, No. 146, $10-12$.

2 nam-š usually has the meaning "for, because of " or "in place of ". See SBP. 170, 14; 262, 20. Thureau-Dangin, SAK. $216 a, 27 ; 220 e, \mathrm{ii}, 5$; SBP. 60, 5-14. Note, for the original sense "in place of", Ebeling, Religiöse Texte, 14, iii, $38=\mathrm{iv,} \mathrm{R.} \mathrm{13b,} \mathrm{36,} \mathrm{nam} \mathrm{guškin- \not ̌} u=$ kima hurași. For $n a m-s ̌ r i=$ unto, see line 67 .

3 We expect $n u-b a r=l i k \hat{u}$, adopted son, but the text has apparently the sign $T U G$. Another sign, $B U L U G, D I M$, Thureau-Dangin, REC. $155=$ lika, CT. 12, 20, rev. 7, but the text obviously does not earry this character. Some sign for $l i k \hat{u}$ or tarbîtu should stand here. It is clearly not $E N$. Note also that the sign $B U L U G=l i k n$ is read (?-)ug, possibly tu-ug in CT. 12, 20 , rev. Consequently we may assume that $t u g=l i k \hat{u}$, orphan. The sign is clearly written in line 27 , where the photograph shows a slanted stroke at the right, omitted in Clay's copy. 
22. $n u$ ama-mu

23. be-an-dúg

24. é $a$-šag giš-šar

25. arad arad nig-ga-ra ${ }^{1}$

26. $\grave{2} b-t a-\grave{e}-a$

27. $u \operatorname{tug}(?)-b i$

28 šàm til-la-a-ni-š

29. in-na-ab-sum-mu

30. $a d-d a-n i$ u ama-ni

31. $n u$ dumu- $[m u]-m e s$

32. ba-an-na-dug

33. $g a^{2} \dot{e}-t a$ bar-ra-e(d)-a
22. not my mother"

23. has said,

24. of house, field, garden

25. slaves and property

26. shall he be disinherited;

27. and that adopted child (?)

28. for his full price shall

29. he sell.

30. And if his father and his mother

31. "Not our son"

32. said to him,

33. they shall be deprived of utensils (?) and house.

The laws on adoption in the Code $\S \S 185-93$ do not provide for cases of renunciation either by parents or children. We could assume from the vague Sumerian law above that adoption carried with it the right of inheritance, which was clearly not involved by adoption according to Semitic law ( $\S 190-1$ ). A Semitic contract published and edited by Ungnad and edited also by Schorr ${ }^{3}$ has a special clause in which the adopted son is assured to his right of inheritance. In this contract the following phrase occurs: "If in future days S. to B. and $\mathrm{H}$. shall say, 'Thou art not my father, thou art not my mother,' they shall cut a mark upon him and sell him for money. And if $B$. and $H$. to $S$. their son shall say, "Thou art not our son,' they shall leave house and utensils." Semitic contracts of adoption involve inheritance only by special clause. ${ }^{4}$

1 For nig-ga-ra, early form of nig-ga = makkuru, v. BE. 31, 19, 9.

2 This sign is read $U B$ by Clay. We expect here a word for unätu, utensils. Cf. Schorr, ibid., No. 8,26 , ina bîti uniāti itelu (the parents who deny their adopted son) shall be deprived of house and utensils. The most probable reading seems to be $G A$. Naturally ga may be an error for nig-ga, property, cf. Poebel, ibid., No. 24, 26.

${ }^{3}$ VS. viii, 127 (formerly published by Meissner) = Schorr, Altbabylonische Rechtsurkunden, No. 8. It is dated in the 14th year of Hammurabi.

4 Sohorr, No. 9. Ungnad-Kohler, Hammurabi's Gesetz, 19, 20, 22, 23. JRAS. OCTOBER 1920. 
Fortunately a few Sumerian contracts of adoption have been recovered, and these illustrate the Sumerian legal practice on this point. Four contracts of this kind are edited by Poebel, B.E. vi, pp. 27-34. Here two kinds of adoption are clearly intimated by the terms nam-dumu, "sonship," and nam-ibila, "heirship"; when the latter term is inserted the adopted son or daughter is entitled to inheritance. It is obvious, when the Sumerian law above orders the adopted son to leave house, garden, etc., that the case of a fully adopted son is under consideration. In these contracts the clause for full adoption is nam-dumu-ni-šć ba-an-da-an-ri ${ }^{1}$ nam-ibil-a-ni-šú in-gar, "He took him to sonship and made him into heirship." 2 The difficult sign rendered $t u g=l i k \hat{\imath}$ in the law above has no similarity to the sign $R I$, which, because of its legal connexion, should be employed for " adopted son ".

The Code does not contemplate a similar case for a real son, but only the case of a son who has twice committed a grave offence against his father, $\S 169$. The son is expelled from his inheritance. The law reads abûm măr-šu ina aplûtim inazah, "The father shall expel his son from heirship." For this Semitic phrase the Sumerian has ad-da dumu-ni nam-ibil-ta $i b$-ta-an-s $a_{9}$ " "The father removed his son from sonship." 4 The phrase of this law in lines $24-9$ corresponds almost literally to the penalty imposed upon an adopted son in Sumerian contracts. $^{5}$ Sumerian and Semitic contracts also impose penalty of sale into slavery upon an adopted child who denies his parents. The interpretation of this law on the basis of

1 II Raw. 9b, 60, has a false translation ana marûti-ร̌u it-ru-šu (for $i l k i-\breve{s} u)$. On the other hand, the phrases for ejecting a son from his heritage is given in this same text, Col. 1i, $14=$ RA. 14, 14, nam-dumu-a-ni-ta $i b-t a-a n-s a r=a n a$ (error for $i n a)$ marâti-̌̌ itrusu, " he expelled him from sonship." Ibid., 16, nam-apil-a-ni-ta ib-ta-an-zi=ana (error for ina) aplâti-šu issuh-š, "he ejected him from heirshıp."

2 Poebel, No. 24,5 f. Cf. 28,4 ; 23, 22, abbreviated to nam-ibila-ni $b a-a n-d a-r i-a$.

${ }^{3} s a$ is for $s a g ́$ a variant of $s u \dot{g}=$ nasāhu.

4 Genouillac, Inventaire, 5276, rev. 5 .

5 Poebel, No. 24, 18-20. 
its application to cases of disavowal of parents by adopted chililiren is strongly supported by many legal documents.

$\S 22$

34. tukundibi

35. $\operatorname{tug}(?)^{1} a d-d a-n i$

36. ì amx-ni

37 nu dumu-mu-mes

38. [é ?] ̈ù(?) uru

39. $[i b-t a]-e(d)-a$

40. tukundibi

41. dumu-sal galu e-sir-ra

42. $e^{\prime}-i m-g i^{3}$

43. $a d-d a-n i$

44. ì ama-ni

45. $n u-b a^{5}-a n-z u-u s$

46. $k a-a r-a b^{6} \dot{a}$

47. nam ad-ni ù ama-ni ${ }^{\top}(?)$

48. ni-dug-e

49. $a d \cdot d a-n i$
34. If

35. to an adopted son (?) his father

36. and his mother

37. "Not our son" (said)

38. from house (?) and (?) city

39. shall they be compelled to go.

\section{$\S 23^{2}$}

40. If (a man)

41. the daughter of a freeman in the street

42. took for a bride ${ }^{4}$

43. and her father

44. and her mother

45. knew it not,

46. "I . . . her"

47. to her father and mother (?)

48. he shall say.

49. Her father

1 There are traces of a small sign on the tablet before $a d$, as we are bound to expect. This section represents a variant of lines $30-3$, and proves that this code is a compilation of laws which are not altogether consistent with each other.

2 This paragraph was edited by the writer in the Journal of the Society of Oriental Research, vol, iii, 82-3.

3 é-gi, "to confine in a house," is connected with the word $e^{\prime}-g i$-a $=k a l l a t u$, bride, and refers to the custom of confining a newly married couple to the house for a short period after marriage. This custom is referred to in the Code of Hammurabi, $\$ 176$ ištu innemdu, "after they had dwelled together." See, for a full discussion of this custom, p. 82 of JSOR., vol. iii.

4 The phrase is pregnant here and clearly refers to an illegitimate honeymoon or bridal confinement. Literally, "he confined her to a house."

5 Text $z u$.

${ }^{6}$ Or $D U(?)$.

${ }^{7}$ Sign $S A B$ ! It is possible that ka-ar-ab is a precative verbal prefix in the lst person for ga-ra-ab (verily I will ....). 
50. $\grave{u}$ ama-ni

51. nam-dam-ni-š́u

52. in-na-ab sum-mu

\section{3. tukundibi}

54. dumu sal galu e sir-da

55. $\dot{e}-i m-g i$

56. $a d-d a-n i$

57. ì ama-ni

58. $b a-a n-z u-u \check{~}$

59. galu é-im-gi

60. in-dib in-tar

61. e dingir-ira?

62. in-?

63. tukundibi

64. gud nigin-no, ${ }^{1}$

65. ur-mag̀ e-kirr-e

66. gab-ri

67. nam lugal-la-ni-šú

68. $i b-r i-r i^{2}$

69. tukundibi

70. gud nigin-na

71. gud ú-gu ba-an-de

72. gud gud-gim

73. [lugal $a-n i-s ̌ u ́]$

74. [in-na $a b-s u-s u]$
50. and her mother

51. unto wifehood

52. shall give her to him.

$\S 24$

53. If (a man)

54. the daughter of a ireeman from the street

55. took for a bride,

56. and her father

57. and her mother

58. knew of it

59. he who took her for a bride

60. shall be seized and judged.

61 . In the house of god ...

62. he shall ...

\section{$\S 25$}

63. If

64. an ox-herd allows

65. a lion to devour (an ox),

66. a substitute of equal value

67. to the owner

68. shall he present.

$\S 26$

69. If

70. an ox-herd

71. allow an ox to be lost

72. ox for ox

73. [to its owner]

74. [shall he restore $]^{3}$

1 Literally, "one who confines oxen." The Semitic law § 262 probably had nākidu.

2 Or en, enphatic ending? gab-ri ri-ri = mahäru mihra, to present a substitute Cf. gab-ri [ ].= miļra muhurur, CT. 19, 42, 23, and for $r i=$ mahāru see AO. 3930, Obv. 12, and RA. 10, 77, 8 .

3 iriab; see the Code of Hammurabi $\$ 219$ and above, Sumerian law, $\S 4$, line 13 . 


\section{AdDendum \\ The Sumerian original of Ellasar}

In the text of my paper I have returned to the Biblical form of the name of the city of the sun-god in Sumer, now the ruins of Senkereh. Genesis xiv, 1, mentions Ariôch, king of Ellasar, which has been correctly identified with Larsa, the Babylonian pronunciation of the name. But the old Sumerian pronunciation, as hitherto accepted among Assyriologists, was supposed to be Zarar or Arar. The present views about the name are unsatisfactory, and it is obvious that there was something wrong about our knowledge concerning the history of the word. The Sumerian ideogram for the name of this city is $U D-U N U-(k i)$, "Abode of the sun-god," and Raw. v, 23, 30, indicated that the name was pronounced Zarar-ma, but the new copy in CT. xi, 35, showed that $Z A$ is uncertain and that $A$ may be correct. Some scholars have adopted Arar-ma or Arar as the true rendering. The ending $m a$ which is also added frequently to the name of the city of Ur, i.e. Uri-ma, is an old locative ending $a k a$, $a g a, a m a>m a$, and is commonly omitted.

$Z A-r a-a \dot{r}$ is certainly correct, for the sign $Z A$ has the value $i l$ or ila here, and the Sumerian should be pronounced Ilarar. The value $i l$ for $Z A$ resorts from a Berlin syllabary, Schroeder, Keilschrifttexte aus Assur, No. 216, 9, where the divine name $Z A-M A L-M A L$ is read Ilbaba. Ilrar by dissimilation, or $r>s$, gave Ilsar or Ilasar.

A great many examples of alveolar $r$ passing into sibilant $s, \breve{s}$ have been given in $\$ 46$ of my Sumerian Grammar. The Hebrew rendering is based directly upon the Sumerian, which proves the antiquity of Genesis xiv. The Babylonian Larsa is a distortion of Ilrar, Ilasar by metathesis. 